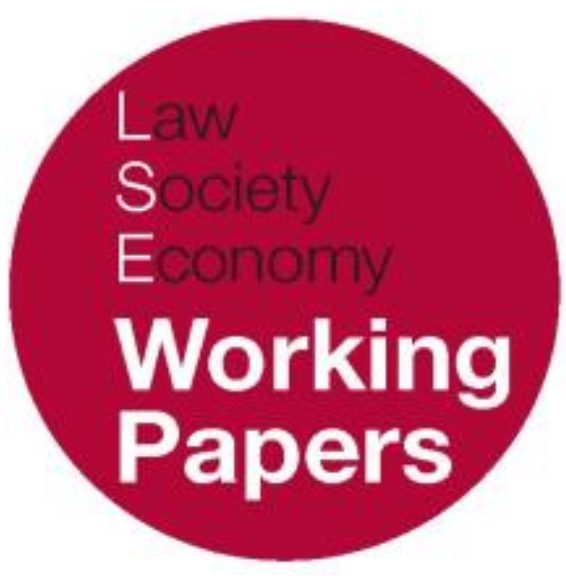

\title{
Repo and Derivatives Portfolios \\ Between Insolvency Law and Regulation
}

\author{
Philipp Paech
}

LSE Law, Society and Economy Working Papers 13/2017

London School of Economics and Political Science

Law Department

This paper can be downloaded without charge from LSE Law, Society and Economy Working Papers at: www.lse.ac.uk/collections/law/wps/wps.htm and the Social Sciences Research Network electronic library at: https://papers.ssrn.com/sol3/papers.cfm?abstract_id=2984199. (C) Philipp Paech. Users may download and/or print one copy to facilitate their private study or for non-commercial research. Users may not engage in further distribution of this material or use it for any profit-making activities or any other form of commercial gain. 


\title{
Repo and Derivatives Portfolios Between Insolvency Law and Regulation
}

\author{
Philipp Paech *
}

\begin{abstract}
In the general perception, financial institutions' immense repo and derivatives portfolios are friends and foes alike: friends, because they provide for levels of market liquidity that would be unimaginable without them. Foes, because both types of transactions are somehow regarded as being unstable and volatile in their nature, potentially exacerbating and accelerating crisis situations. This tension is also reflected in the treatment of repos and derivatives in the event of a corporate crisis. Insolvency law and relevant regulation seem to support and protect repo and derivatives transactions, while at the same time imposing limits on them, trying to balance liquidity arguments with those relating to stability. This paper concludes that regulation is better placed than insolvency law to address systemic stability concerns, whereas relevant insolvency rules guarantee high levels of liquidity while they are ineffective in terms of stability. The paper will concentrate on EU and US law, complemented by international benchmarks. It expands on certain aspects first developed my earlier paper on insolvency safe harbours. ${ }^{1}$
\end{abstract}

\footnotetext{
* Assistant Professor of Law and Finance, Department of Law, London School of Economics and Political Science.

${ }^{1}$ P. Paech, The Value of Insolvency Safe Harbours (2016) Oxford Journal of Legal Studies 36(4) 855.
} 


\section{INTRODUCTION}

Banks and other financial institutions typically hold significant portfolios containing sale and repurchase ('repo') and derivative contracts. The former are an important means of financing, remotely comparable to a secured loan. ${ }^{2}$ The latter are contracts that serve for purposes of hedging against market or credit risk and are remotely comparable to insurance contracts. ${ }^{3}$ Both functions are vital to every individual financial institution and play an important role in the functioning of the modern financial market. As a consequence, the treatment of repo and derivatives portfolios in times of crisis has significant influence on the future viability of an ailing institution and on the stability of the market as a whole.

In times of corporate crisis, from the perspective of an ailing financial institution the core question is whether the contracts will survive the crisis and can hence continue to provide their vital functions. If they cease to exist, in particular because they are terminated by the relevant counterparties, the ailing institution faces a significant financing gap and will be un-hedged in respect of significant parts of its exposures. Obviously, that outcome may exacerbate the institution's unstable status and probably even push it over the brink.

The perspective of the ailing institution's counterparties presents the inverse view, at least to a large extent. They would, in principle, prefer to terminate contractual relationships, if necessary enforce available collateral in order to be able to refinance and re-hedge elsewhere. Thus, they will not get entangled in the ailing institution's liquidation, or respectively, restructuring or resolution procedures.

The perspective of the market as a whole is tricky. There may be both good reasons for keeping intact repo and derivative portfolios of an ailing financial institutions, and for terminating them.

The first layer of arguments is linked to the fact that jurisdictions as a matter of policy lean more towards one or the other solution. From the viewpoint of a jurisdiction that is generally more debtor-friendly and favours restructuring over liquidation, maintaining the contracts helps keeping the ailing institution afloat. In more creditor-friendly jurisdictions, the argument is rather that assets should be channelled back into the economic cycle quickly, even at the cost of liquidating the relevant ailing business.

\footnotetext{
2 The semi-annual market survey of the relevant market association, ICMA, reveals that its 65 participating European members had repos worth EUR 5.65bn outstanding on their books in December 2016. See http://www.icmagroup.org/Regulatory-Policy-and-Market-Practice/ short-term-markets/RepoMarkets/repo/latest/.

3 The global open interests in exchange-traded futures and options market stood at 26tn USD in December 2016; the global market value of otc derivatives stood at 20tn market value in the first half 2016, see http:/ / www.bis.org/statistics/about_derivatives_stats.htm?m $=6 \% 7 \mathrm{C} 32 \%$ 7C639.
} 
However, legislators take further elements into account, especially in the context of banking and finance. Here, at a second level of argument, systemic stability concerns are factored in, assuming that allowing for the counterparties to pull out of the contracts quickly helps avoiding contagion, comparable to immediately quarantining an infectious patient. Links to other market participants are severed by allowing them to quickly terminate all repo and derivatives transactions. However, the argument may not always be clear-cut: mass termination of contracts can also cause adverse externalities, such as asset price depreciation, depending on circumstances.

A third level of that argument relates to liquidity. Legislators and market participants alike strive to generate high levels of liquidity in order to support financial activity and growth. The basic idea is that by favouring those that offer repo and derivatives contracts more financial activity can be generated - very much like it is generally assumed that the possibility to take security for credit fosters the lending market and therefore investment. To this end, repo and derivative counterparties are afforded a favourable insolvency treatment, notably by allowing to cut lose immediately, as described before. Many link the exponential increase in repo and derivatives activity during the run up to the recent financial crisis also to this favourable treatment. ${ }^{4}$

These three levels of arguments are difficult to disentangle in practice: rules that appear to have negative consequences for the failing institution are at the same time generally favourable for repo or derivatives creditors, while they may be either useful or even dangerous from the perspective of the market as a whole.

Legislators cast their view on these issues into legal norms. These norms are either part of the insolvency law, which is the area of law that traditionally dealt with the question of how contracts with a business in crisis are treated. Or, relevant norms take the form of regulation, $i e$ ordering or forbidding certain types of behaviour. As a result, the picture of relevant rules and their effects on stability and liquidity is extremely complex, also because it is quickly evolving since the last financial crisis. In this paper, I will show that, contrary to common perception, the function of so-called insolvency safe harbours is to enhance liquidity, while regulatory rules are needed to protect the financial system from contagion.

In the second section, I will assess the effect of insolvency safe harbours, which are insolvency rules notably flowing from the implementation of the Financial Collateral Directive in the EU, and from changes brought over the time to Title 11 of the USC, in terms of their effect on systemic stability and liquidity. This section comes to the result that the case for systemic protection through safe harbours is relatively weak. Rather, their main function is to provide for high levels of liquidity in the repo and derivatives market, notably by allowing for highly efficient use of associated collateral.

${ }^{4}$ See Bank for International Settlements, Quarterly Review, December 2008

<http://www.bis.org/publ/qtrpdf/r_qt0812e.pdf> accessed 10 March 2015. 
The third section is focussed on the novel alternative to insolvency, notably bank resolution, as enshrined in the Bank Recovery and Resolution Directive and the Dodd-Frank Act. Here, the stance in respect of repo and derivatives portfolios is fundamentally different from the approach under insolvency law, and rules comparable to safe harbours do not exist in this context. As a consequence, since the introduction of bank resolution schemes, the insolvency safe harbours will hardly ever be used, at least not in systemically relevant bank failures.

I will then move on, in the fourth section, to show that systemic implications of bank failures, including the implications connected to big repo and derivatives portfolios, are addressed in a variety of regulatory regimes. First, bank capital regulation sanctions the liquidity created by safe harbour and treats them as an integral part of the regime that is designed to render banks resilient against market stress. Second, a number of other rules address systemic implications flowing from the highly efficient use of financial collateral associated with repo and derivative transactions. They are designed to protect markets from downward spirals of asset prices, under-collateralisation and network effects.

Section 5 concludes.

\section{INSOLVENCY LAW}

The insolvency law of most developed financial markets ${ }^{5}$ affords a creditorfriendly treatment to repo and derivatives counterparties in case a financial institution fails or becomes insolvent. In the EU this area of law is harmonised, notably on the basis of the Financial Collateral Directive. Hence, similar rules addressing this issue can be found in all $28 \mathrm{EU}$ jurisdictions. In the US, the matter is addressed in Title 11 ('Bankruptcy') of the United States Code, covering both liquidation in its Chapter 7 on and reorganisation in its Chapter 11. The relevant rules on both sides of the Atlantic have largely identical functional effects. They are called 'insolvency safe harbours' in the context of US law, however, there is no similarly handy term to described the rules of the FCD. Hence, I use 'safe harbours' throughout this chapter, meaning both the EU and the US rules.

\subsection{The FCD AND USC TITLE 11}

The insolvency safe harbours of the FCD and USC Title 11 afford a special treatment to repo and derivative portfolios that protects the relevant parties from the usual effects of insolvency law should one of them fail. The mechanism of that

\footnotetext{
${ }^{5}$ ISDA currently lists 57 jurisdictions that largely allow for quick termination, set off and enforcement of collateral as soon as a financial market participant becomes insolvent, see <http://www.isda.org/docproj/stat_of_net_leg.html\#f1>.
} 
protection is identical in both jurisdictions: the parties agree on a set of risk mitigation tools, in particular close-out netting and collateral, in their derivative and repo master agreements (in particular, ISDA and GMRA respectively). The clauses would normally be at risk of unenforceability should one of the parties fail, as they conflict with various general insolvency rules, notably those designed to protect the pari passu principle. However, the FCD and certain rules in USC Title 11 protect these contractual clauses. How this protection works can be best described by referring to three different functional elements.

The main element of that protection consists of insolvency law rules upholding contractual clauses that allow the liquidation of repo and derivative portfolios, even in the run up to insolvency and beyond the opening of relevant proceedings. These clauses typically provide for the solvent party to be allowed to 'close-out', meaning that all repo and derivative contracts are terminated, that their market value (typically equivalent to the replacement cost) is determined, and that positive and negative values are set off to form a total net amount. This sum is very small in relation to the face value of the contracts and is to be paid from the party that is 'out of the money' to the one that is 'in the money'. If insolvency proceedings have been opened over the party that is out of the money, the party that is in the money has to claim that sum from the insolvent estate as a general creditor, unless it is collateralised. Under the rules of the FCD and those contained in Chapter 11 USC agreements to that effect remain enforceable. ${ }^{6}$

Further, safe harbours in the EU and the US protect what would outside the financial context be regarded as the late provision of collateral and amount to preferential treatment of a creditor. Financial parties generally include clauses in their contractual arrangements to the effect that collateral levels are constantly adjusted to properly reflect the relevant exposure flowing from the portfolio. As parties typically collateralise the anticipated net amount (ie after setting off contractual values, see above), the value of the collateral is regularly adapted to properly reflect the constantly changing anticipated net amount. This includes situation where the party that has been in the money so far becomes the party that is out of the money at a later stage, entailing a shift in who has to provide collateral to whom. This process is called margining. As margining is an on-going process the concept collides markedly with general insolvency rules that allow avoiding provision of collateral to the solvent counterparty if it occurred too close to the opening of liquidation proceeding, say during the last 3 months prior to insolvency. The background of the general rule is that late provision of collateral tends to disadvantage other general creditors of the insolvent. The Financial Collateral Directive and USC 11 protect margining, on the assumption that it only occurs to reflect changing values of the repo and derivatives portfolios and hence does not actually disadvantage other creditors. ${ }^{7}$

${ }^{6}$ Articles 4(4), 7(4) Financial Collateral Directive; 11 USC SS 362(b)(6)-(7)-(17)-(27) and (o); 555-556, 559-561.

${ }^{7}$ Article 8(1)-(3) Financial Collateral Directive; 11 USC S 546(g), (j). 
Equally important is the fact that in respect of repo and derivatives portfolios, insolvency law allows for swift enforcement of collateral in case of insolvency of the counterparty, regardless of the approach followed by the general insolvency law of the relevant jurisdiction. ${ }^{8}$ There is no waiting period or the need to apply to the receiver. Also, no special procedure, such as public auction of the collateral assets, has to be followed. Typically, the solvent counterparty can realise the collateral by selling it at market price. If contractually allowed, it might even be able to just hold on to it and apply its value to the outstanding debt.

\subsection{EFFECTS ON LIQUIDITY}

The liquidity rationale of the protection afforded by safe harbours has never received the same degree of prominence as the financial stability rationale, as described in the next part. ${ }^{9}$ On the face of it, safe harbours produce economic effects quite similar to those associated with the protection of traditional security interests in insolvency. ${ }^{10}$ Because parties need not worry about their counterparty's solvency, derivatives and repo contracts become more easily available, and at a reduced cost. As a result, the basic economic effect of safe harbours is considerable growth in volumes of the relevant types of transaction and more efficient allocation of assets.

In considering whether to introduce insolvency privileges, legislators must take into account the fact that such privileges almost automatically entail a shift of the risk from one segment of the market to another, the latter being potentially 'weaker' creditors. In this regard, too, there are no fundamental differences between traditional security interests and the protection afforded under the FCD. Therefore, the basic assumptions about liquidity and the resulting discussion about the overall social value of insolvency privileges are very similar to those prevailing in the case of traditional security interests ${ }^{11}$ and will not be addressed here. Rather,

\footnotetext{
${ }^{8}$ Article 4(4) and (5) FCD; 11 USC \362(b)(6)-(7)-(17)-(27) and (o).

${ }^{9}$ See RR Bliss, and GG Kaufman, 'Derivatives and Systemic Risk: Netting, Collateral, and Closeout', Federal Reserve Bank of Chicago Working Paper 2005-3 (2005), 66

$<$ http://papers.ssrn.com/sol3/papers.cfm?abstract_id=730648 > accessed 10 March 2015. See Recitals 12 and 19 Financial Collateral Directive. See also ISDA, Memorandum on the Template for Netting Legislation (March 2006) < http://www2.isda.org/search?headerSearch =1\&keyword=model+netting $>$ accessed 10 March 2015, where the word 'risk' appears eight times, whereas 'liquidity' is not mentioned at all; American Bankruptcy Institute (ABI), Commission to Study the Reform of Chapter 11 - Final Report and Recommendations (2014) 94-95 < https://abiworld.app.box.com/s/vvircv5xv83aavl4dp4h> accessed 10 March 2015, Section IV.E on 'Financial contracts, derivatives and safe harbour protection' mentions liquidity as a policy argument only once, and in the context of a side issue, whereas 'stability' is referred to eleven times.

${ }^{10}$ See V Finch, 'Security, Insolvency and Risk: Who Pays the Price' (1999) 62 Modern Law Review 637-643.

${ }^{11}$ See, eg, Finch, ibid; LA Bebchuk and J Fried, 'The Uneasy Case for the Priority of Secured Claims in Bankruptcy' (1996) 105 Yale Law Journal 857-934.
} 
I will concentrate on four novel effects of safe harbour rules that represent a quantum step in terms of increasing liquidity, in particular as their effects combine.

\section{Flexibility Across Legal Categories and Asset Types}

The risk mitigation techniques of master agreements, as protected by safe harbour rules, are used to abolish established legal boundaries. In particular, differences between full title and security interest disappear, and boundaries between claims, cash and securities become blurred. This high degree of flexibility is nothing less than revolutionary, overthrowing traditional legal restrictions on the use of assets with a view to obtaining cash and creating liquidity more generally.

First, the differences between full title and security interests disappear because the safe harbours sanction the use of title transfer collateral, netting and margining. ${ }^{12}$ Under such arrangements, while the collateral provider is protected as efficiently as it would be under a traditional security interest such as a pledge or mortgage, the collateral taker enjoys far greater freedom to use the collateral assets than it would under a traditional security interest, in that it becomes the legal and beneficial owner of the asset and can therefore dispose of it, without being obliged to return that specific asset as long as the asset returned is of the same kind. What is remarkable here is that the rights of one party appear to grow whereas the risk borne by the other party remains unchanged.

Furthermore, the boundaries between claims, money and securities become blurred as the collateral provider can validly substitute new collateral assets for the assets originally provided, which it might need for other purposes. ${ }^{13}$ The only proviso is that the replacement assets must be of substantially equivalent value. As a consequence, the collateral provider is allowed to replace one kind of securities collateral for another, or give cash for securities collateral, or claims for cash collateral, etc.

On that basis, the specificity of the collateral assets becomes as irrelevant as their nature (money, claims or securities). Positions become interchangeable and the collateral provider will collateralize all available assets as efficiently as possible, thereby creating maximum return. The fact that assets are freed from the conceptual burdens associated with legal limits to traditional security interests means that they can be treated as mere accounting positions, the only parameter being current market value. Thus, thanks to the existence of safe harbours, a portfolio resembles a gigantic current account into which assets and liabilities, including collateral of whatever description, accruing under whichever type of arrangement, can be booked at current market value, so as to show the net exposure as a grand total.

\footnotetext{
12 'Margining' is necessary because both the obligation and the value of the collateral asset typically change over time. Therefore, collateral levels are adjusted to the exposure on a daily basis. The obligation to post collateral might reverse in the course of the term of the contract; see, eg, Article 8(3) Financial Collateral Directive.

13 'Substitution' describes the right to withdraw financial collateral on providing, financial collateral of substantially the same value, see, eg, Article 8(3)(b) Financial Collateral Directive.
} 


\section{Efficient Use of Collateral}

A phenomenon closely connected to the foregoing is the fact that safe harbour rules enable collateral to be allocated so efficiently that there will hardly be any collateral buffers around. The first aspect here is the effect of the enforceability of close-out netting on collateral levels. If a risk reduction of $80 \%$ can be taken for granted, ${ }^{14}$ parties would, of course, only collateralize the remaining $20 \%$. Hence, much less collateral will be needed from the outset or, to put it differently, the same amount of collateral will suffice to cover a higher volume of transactions.

At the same time, master agreements make it possible constantly to adjust collateral levels to the underlying exposures so as to avoid over or undercollateralisation. These margining mechanisms rely on a significant limitation of avoidance powers as provided by the safe harbour rules, as they might otherwise be classified as late provision of collateral (see above).

Lastly, safe harbours enable the re-use of collateral assets by the collateral taker, given that the latter generally becomes their legal and beneficial owner. Therefore, as opposed to what is common in other markets (which are bound to traditional secured transactions, lack of safe harbour protection), the collateral taker will generally put the collateral assets to use instead of just 'holding' them, thereby maintaining the assets in constant flow.

The result of the foregoing is that asset allocation is extremely efficient throughout the market. However, by the same token, it may also mean that the cover becomes extremely thin, as there are no longer any pools of unused assets.

\section{World-wide Use of Collateral}

Collateral assets are scarce and sourcing them from a wider market would therefore be beneficial in terms of liquidity. However, before the broad introduction of insolvency protection for repo and derivative transactions and associated collateral, financial institutions had to rely on domestic secured financing law. The diversity of mandatory insolvency and property law nurtured substantial doubts as to the cross-jurisdictional enforceability of master agreements, in particular regarding their close-out netting and collateral

\footnotetext{
${ }^{14}$ The notional amount (face value) of all types of OTC contract stood at approximately USD 544 trillion at the end of June 2016. The gross market value of these contracts, ie, the cost of replacing all of them by equivalent contracts at the market price, was approximately USD 20.7 trillion. This amount corresponds to the gross market risk inherent in these contracts, ie, market participants were, on an aggregate basis, exposed to each other by that sum. At the same time, market participants' aggregate actual credit exposures, ie, the remaining credit risk taking into account legally enforceable master agreements, amounted to USD 3.7 trillion, which represents a risk reduction of about $80 \%$. See Bank for International Settlements, 'OTC Derivatives Statistics at End-June 2016' (November 2016) 11, www.bis.org/publ/otc_hy1611.pdf, accessed on 4 January 2017.
} 
arrangements. ${ }^{15}$ Cross-border collateral was possible but complicated to arrange, and each arrangement was only compatible within the two jurisdictions involved. The Financial Collateral Directive and USC Title 11 create a harmonised regime and led to the de facto abolition of traditional asset-based security interests amongst financial institutions. However, the phenomenon is not confined to the EU or US jurisdictions, as safe harbour rules are relatively homogeneous throughout all jurisdictions that have developed financial markets. ${ }^{16}$

As a consequence, there is a harmonized legal space in which financial institutions can source and use collateral quasi-globally. The fact that there is now a level legal environment is illustrated by the circumstance that transactions can be documented in different markets under the same master agreements. In particular, the ISDA and GMRA master agreements have gained global significance ${ }^{17}$ because their functionalities (termination, liquidation, set-off, collateral) are now recognized in the relevant jurisdictions. At the same time, the restriction of avoidance powers removes fears of re-characterisation, claw-back and similar court actions. Despite the fact that many legal differences remain as to detail, it is probably fair to say that the market for collateral, and therefore the market for derivatives and repos, comes close to having a globally harmonised legal framework. The extensive introduction of insolvency protection for repo and derivatives contracts is actually a significant example of market-driven high-impact international legal harmonisation, ${ }^{18}$ somehow silently overcoming statutory legal hurdles from which parties traditionally could not derogate. Mandatory insolvency and property law typically constituted the most significant threats to the enforceability of contracts. However, at statutory level, despite considerable efforts, to date States have been unable to agree on a legal framework that is compatible across borders. Sectoral harmonisation on the basis of the FCD, USC Title 11 and similar rules in other jurisdictions not only lessens the importance of domestic policy in matters of insolvency but also reduces the importance of legal considerations in risk management to a significant extent.

\subsection{EFFECTS ON FINANCIAL STABILITY}

At the surface, the safe harbour protection serves to decrease the risk inherent in the financial market. ${ }^{19}$ The significant limitation of individual counterparty credit

\footnotetext{
15 See, regarding enforceability of collateral: P Paech, 'Market Needs as Paradigm - Breaking up the Thinking on EU Securities Law', in PH Conac, L Thévenoz and U Segna (eds), Intermediated Securities, (Cambridge University Press, 2013), 22-64; in relation to enforceability of close-out netting: 'Close-out Netting' (n 6).

${ }^{16}$ See above, $2^{\text {nd }}$ Part.

${ }^{17}$ See Briggs J in Lomas \& ors v JFB Firth Rixson, Inc \& ors [2010] EWHC 3372 (Ch) at [53].

18 See Bliss and Kaufman, 'Derivatives and Systemic Risk' (n 9) 56.

${ }^{19}$ See, in particular, Basel Committee on Banking Supervision, 'Report and Recommendations of the Cross-Border Bank Resolution Group' (2010) 36-40 < http://www.bis.org/publ/bcbs 169.pdf $>$ accessed 10 March 2015. For US legislative history, see C Mooney, 'The Bankruptcy
} 
risk is expected to have a beneficial effect on financial stability. In other words, privileges afforded to counterparties of a failing institution would translate into advantages benefiting the market as a whole. This argument is particularly relevant to the financial sector, even more so than to other sectors, as financial institutions are so closely intertwined. ${ }^{20}$ Network externalities are therefore much more likely to occur than they are in other industries, and furthermore spread from the financial sector to invade entire economies. ${ }^{21}$ On the basis of this broad argument, safe harbour rules have been successively introduced in many jurisdictions.

However, it might be argued that specific insolvency 'privileges' for repo and derivative portfolios may also create systemic risk rather than curb it. ${ }^{22}$ Thus, while, on the one hand, credit risk contagion is effectively inhibited by close-out netting and collateral as protected by the safe harbour rules, it is also true that, on the other hand, these mechanisms can at the same time develop adverse systemic effects through other transmission mechanisms. ${ }^{23}$ Broadly speaking, relevant examples fall into two categories of risk transmission mechanism, to wit, moral hazard and collateral/liquidity shortages.

\section{Moral Hazard}

The FCD and the relevant provisions of USC Title 11 create a transaction environment for the parties to repo and derivative contracts that is almost entirely free of counterparty risk. This places financial institutions in a privileged position as compared to other, non-financial counterparties (although the degree of privilege differs from one jurisdiction to another ${ }^{24}$ ). Thanks to these privileges, risk is shifted to non-financial counterparties, including society, which alone have to bear the specific cost of bankruptcy. In that respect, the rules of the FCD and USC Title 11 have an effect quite comparable to that of traditional security interests.

The existence of such a privilege is bound to affect the perception and conduct of market participants generally. As a result, the existence of safe

Code's Safe Harbors for Settlement Payments and Securities Contracts: When is Safe too Safe?' (2014) 49 Texas International Law Journal, 245, 247-251.

${ }^{20}$ FR Edwards and ER Morrison, 'Derivatives and the Bankruptcy Code: Why the Special 'Treatment?' (2005) 22 Yale Journal on Regulation, 111.

${ }^{21}$ Bliss and Kaufman, 'Derivatives and Systemic Risk' (n 9) 66; SJ Lubben, 'Repeal the Safe Harbors', (2010) 18 American Bankruptcy Institute Law Review 319, 329.

${ }^{22}$ See, in particular, Lubben, ibid; Payment Priorities as Financial Crisis Accelerator' (2011) 63 Stanford Law Review 539-589.

${ }^{23}$ K Pistor, 'A Legal Theory of Finance' (2013) 41 Journal of Comparative Economics 315330 , sections 3.2 and 4.3 provides evidence that the antagonising effects of financial law, ie creating and threatening liquidity at the same time, are a general and logical characteristic of the market.

${ }^{24}$ See P Paech, Insolvency Safe Harbours (n 1). 
harbours may provoke moral hazard. ${ }^{25}$ In the context of financial regulation, the term 'moral hazard' describes a mechanism whereby real or presumed guarantees for the financial sector render the financial market more risk-prone on an aggregate basis. The phenomenon has been identified as a major driver of the 2007-2009 financial crisis. For years, financial institutions had enjoyed high income generated by excessive risk-taking in the expectation that the cost of failure would be socialized. After the crisis, a number of regulatory changes were introduced in an attempt to tame moral hazard, with a view to re-allocating to financial institutions and their stakeholders the risk they themselves create. ${ }^{26}$

Shifting the risk as such does not necessarily entail moral hazard. All kinds of insolvency privileges shift risk around the insolvent's various types of creditors. The question, rather, is whether that shift entails a behavioural pattern that increases the risk overall, or, to put it differently, whether the level of systemic risk in the market as a whole increases.

Such an overall rise in systemic risk could be caused in particular by market inefficiencies. Already in relation to traditional security interests, the possibility for bigger players to demand security indirectly subsidizes their businesses at the expense of certain other players, since the latter are unable to adjust to the increased risk. ${ }^{27}$ The effect of the risk transfer caused by insolvency safe harbours is similar: parties to whom risk is shifted are generally remote from the financial sector and as a result lack the ability to monitor the shift and adjust their own behaviour, in particular by demanding a higher risk premium or by not entering into the relevant position or quitting it altogether. ${ }^{28}$ The risk-taming effect of corrective behaviour at that end of the market is lacking, and this in turn renders the distribution of risk inefficient and the market overall riskier. It is worth noting that this shift of risk is global, as in practice all eligible creditors will take the necessary steps to move ahead of the pool by using the safe harbours. ${ }^{29}$ The risk is shifted to those that have no means of improving their position in any insolvency proceedings: in particular depositors, unsecured bond-holders, share-holders and 'ordinary' creditors of the insolvent. It is true that non-adjusting market participants in the proper sense are few, traditionally they included retail depositors (which are now often protected by own preferences and/or deposit insurance) and SME creditors. However, mindful of the too-big-to-fail phenomenon, to which safe harbours contribute by allowing for exponential

\footnotetext{
25 Roe, 'Derivatives Market Payment Priorities' (n 22) 545. See DG Baird, 'Bankruptcy's Uncontested Axioms' (1998) 108 Yale L J 573, 578, 589-592.

26 These measures include remuneration of bank managers, higher bank capital requirements, new bank resolution regimes, stricter regulation of derivatives, introduction of anti-cyclical capital and liquidity buffers, and others. See for an instructive overview <http://ec.europa.eu / finance/general-policy/policy/map_reform_en.htm\#row7> accessed 10 March 2015.

${ }^{27}$ See Finch, 'Security, Insolvency and Risk' (n 10) 639.

${ }^{28}$ Edwards and Morrison, 'Derivatives and the Bankruptcy Code' (n 20) 32, 34; Roe, 'Derivatives Market Payment Priorities' (n 22) 570; Finch, 'Security, Insolvency and Risk' (n 10) 644-645 (in relation to traditional security interests).

${ }^{29}$ See V Finch, Corporate Insolvency Law (2nd edn, Cambridge University Press 2009) 36.
} 
growth of the derivatives and repo markets, the State has traditionally assumed the risk as a whole, so that even adjusting creditors have no need to take the shift of risk into account. 30

Furthermore, security may distort managerial diligence in the choice of counterparties. ${ }^{31}$ As before, this argument can be translated into the context of the privileged treatment of repo and derivative portfolios: financial counterparties rely exclusively on the risk-mitigation tools guaranteed under the safe-harbour regimes instead of investing into ex ante and on-going monitoring of their counterparties. ${ }^{32}$ Yet, such overreliance could also lead to moral hazard. ${ }^{33}$ By contrast, if, in the absence of such protection, monitoring were a necessity, any concentration of risk on certain players would be detected and priced in by potential counterparties; as a consequence, there would be more players with smaller risk portions in the market, and the market would be more diversified overall. ${ }^{34}$ Moreover, in times of crisis, with falling or unclear collateral value, the information obtained through monitoring would allow lending to continue as healthy counterparties could continue to operate even in adverse times..$^{35}$

However, it is moot whether a case of moral hazard can be built on the foregoing. It is not evident that the market becomes riskier overall, as compared to the hypothetical alternative, a market without safe harbours. Hard evidence of such a connexion is difficult to establish and is often attempted with an eye to a preconceived result. ${ }^{36}$ To begin with, obviously, improved monitoring is always beneficial. $^{37}$ Yet the value of monitoring highly complex, international and interconnected counterparties is limited. Comprehensive data regarding the counterparties is unlikely to be available. Even where such data is available, its value is limited as counterparties' balance sheets are not static and are subject to network externalities, since the riskiness of assets depends on the market as a

\footnotetext{
${ }^{30}$ See Roe, 'Derivatives Market Payment Priorities' (n 22) 558-559; JM Peck, R Mokal and T Janger, 'Financial Engineering Meets Chapter 11 Safe Harbors and the Bankruptcy Code' (2011) < http://discovery.ucl.ac.uk/1402065/1/Peck,\%20Mokal\%20and\%20Janger\%20on $\% 20$ Safe $\% 20$ Harbors $\% 20$ and $\% 20$ the $\% 20$ Bankruptcy $\% 20$ Code.pdf $>$ accessed 10 March 2015, 12. It is debatable whether this holds true in all respects. The implicit State guarantee for banks might be regarded as the price paid for having energetic, growth-producing and stimulating financial markets. Although recent regulatory initiatives attempt to remove the State guarantee completely, it is not absolutely certain whether financial markets that go beyond pure utility banking can be governed in a way that makes bail-outs completely unnecessary in the future. See also more generally Pistor, 'A Legal Theory of Finance' (n 23) 323.

${ }^{31}$ See Finch, Security, Insolvency and Risk (n 10) 646.

32 Roe, 'Derivatives Market Payment Priorities' (n 22) 560-561.

${ }^{33}$ Roe, ibid.

${ }^{34}$ Roe, ibid.

35 Roe, ibid 567-568.

${ }^{36}$ Baird, 'Bankruptcy's Uncontested Axioms' (n 25) 589.

${ }^{37}$ See, in particular, efforts to strengthen due diligence regarding counterparties instead of exclusive reliance on credit ratings: Financial Stability Board, 'Principles for Reducing Reliance on Credit Ratings' (27.10.2010) < http://www.financialstabilityboard.org/wp-content/uploads /r_101027.pdf?page_moved=1> accessed 10 March 2015.
} 
whole. ${ }^{38}$ Therefore, the available data says little about the riskiness of a balance sheet in times of stress. In other words, monitoring counterparties to prevent risk is generally useful but not as powerful a tool as reducing counterparty risk through security, collateral and close-out netting — for which the existence of safe harbours is essential.

Speaking more generally, moral hazard, together with the too-big-to-fail argument, are amongst the main phenomena that have been identified as the origins of the recent financial crisis. They are not triggered by the special treatment of repo and derivatives portfolios alone but by an amalgam of causes and incentives and, probably, the fundamental socio-economic set-up of the financial market as a whole. Repealing or restricting safe harbours, as proposed by some ${ }^{39}$ is not, therefore, necessarily a suitable means of removing moral hazard, in particular because safe harbours are concerned above all with enforceability of contractual rights and only have an indirect influence on behaviour.

\section{Collateral/Liquidity Shortages}

When a financial institution fails, the liquidation rights of counterparties will be triggered at some point. The contractual arrangements with basically all counterparties are highly likely to be affected simultaneously..$^{40}$ Such a scenario of mass liquidation can have adverse systemic effects that antagonize the beneficial systemic effects of the protection. ${ }^{41}$

A first example 42 of off-setting systemic benefits and drawback relates to a phenomenon that was a major transmission mechanism for systemic risk during

\footnotetext{
38 See, eg, AG Haldane and RM May, 'Systemic Risk in Banking Ecosystems' (2011) 469 Nature 351-355.

${ }^{39}$ Bliss and Kaufman (n 9); Edwards and Morrison (n 20); Lubben (n 21); E Perotti, 'Systemic Liquidity Risk and Bankruptcy Exceptions' (2010) DSF Policy Paper Series No 8

<http://dare.uva.nl/document/2/114634> accessed 10 March 2015; Peck, Mokal and Janger (n 30); Roe (n 22); D Duffie and D Skeel, 'A Dialogue on the Costs and Benefits of Automatic Stays for Derivatives and Repurchase Agreements' University of Pennsylvania Law School Institute for Law and Economics, Research Paper No. 12-2 (2012) < http://papers.ssrn.com /sol3/papers.cfm?abstract_id=1982095> accessed 10 March 2015; DA Skeel and TH Jackson, 'Transaction Consistency and the New Finance in Bankruptcy' (2012) 112 Columbia Law Review 152-202; ER Morrison, MJ Roe and CS Sontchi, 'Rolling Back the Safe Harbours' (2014) < http://papers.ssrn.com/sol3/Papers.cfm?abstract_id=2484565> accessed 10 March 2015.

40 See, eg, Section 5(a)(vi) ISDA 2002 Master Agreement, the 'cross-default' provision following which a default event will occur if a party defaults on a third-party obligation and the default or the obligation is in excess of a specified threshold amount.

${ }^{41}$ Basel Committee on Banking Supervision, (n 61) para 115; Financial Stability Board, 'Key Attributes of Effective Resolution Regimes for Financial Institutions' (2014) paragraphs 4.3-4.4 and Annex IV <http://www.financialstabilityboard.org/wp-content/uploads/r_141015.pdf> accessed 10 March 2015; see Bliss and Kaufman, 'Derivatives and Systemic Risk' (n 9) 20; Duffie and Skeel (n 39) 10.

${ }^{42}$ See Bliss and Kaufman, 'Derivatives and Systemic Risk' (n 9) 11, 18-19 and fig. 2; Edwards and Morrison, 'Derivatives and the Bankruptcy Code' (n 20) 10-11; Morrison, Roe and Sontchi, 'Rolling Back the Repo Safe Harbors' (n 39) 14-16; Roe, 'Derivatives Market Payment Priorities' (n 22) 545-546.
} 
the recent financial crisis. The failure of a major participant in the highly concentrated derivatives market causes a liquidity and collateral shortage. The FCD, on the one hand, protect the market from these failures because the relevant counterparties can have recourse to close-out netting and seize collateral. Thus, the failure of a major player is unlikely immediately to cause further insolvencies through the domino effect. However, all the insolvent's counterparties would need to replace all terminated contracts in order to re-hedge their open positions, ie, a large number of new contracts would be created elsewhere in the market within a very short time frame. Fire-sale liquidation of collateral and the sale of further assets to be able to post cash collateral under the new contracts might considerably depress asset prices and might still push the entire market into a collateral crunch.

A second example ${ }^{43}$ relates to the situation of financial institutions that are already ailing but not yet technically insolvent, or in relation to which no proceedings have as yet been opened. Does the protection of close-out netting and collateral arrangements exacerbate or improve their financial position? On the one hand, if parties are properly collateralized, close-out netting and collateral arrangements ensure that a market participant is able to continue trading, since as long as there is no actual failure (or other termination event), its counterparties will see no immediate need to pull out of the relationship. ${ }^{44}$ Thus close-out netting and collateral, at this stage, can help to prevent a further deterioration of the financial position of an ailing firm. On the other hand, it might be argued that as soon as the market becomes aware of financially deteriorating conditions, collateral arrangements will lead to calls for additional collateral, since the collateral taker will have initially made do with collateral the value of which was inferior to the actual exposure (which is common practice between financially healthy parties). This would force the ailing firm into a liquidation of assets in order to meet these demands and spark a depression in asset prices, as the valuation of assets is based on market price ('mark-to-market'), thereby further aggravating the situation. The moment the firm failed to provide sufficient collateral to one of its many counterparties, thereby triggering close-out, cross-default clauses would ensure that virtually all contracts with other market participants were closed out at the same time, thus leaving the firm totally unhedged. Its financial position will prevent it from replacing these hedges at market price, a situation guaranteed to propel it over the brink of insolvency very quickly, rendering any further attempts at restoring viability useless.

However, the above example does not concern the idea of safe harbours as such. Rather, it relates to the phenomenon of insufficient levels of initial

\footnotetext{
${ }^{43}$ See Bliss and Kaufman, ibid 10, 19. Roe, ibid 565-566; see also Edwards and Morrison, ibid 91, 94, 101 (citing the example of the failure of Long Term Capital Management (LTCM) in 1998).

${ }^{44}$ See Morrison, Roe and Sontchi, 'Rolling Back the Repo Safe Harbors’ (n 39) 9.
} 
collateralisation. Parties use the freedom to adjust (!) collateral levels in 'good times' de facto to suspend the provision of any initial margin for an indeterminate period, notably as long as the obligor is financially sound. ${ }^{45}$ Apart from the fact that this practice could be exactly regarded as a preference in that it does not merely reflect a changing obligation, ${ }^{46}$ it is also problematic in terms of systemic risk; no great flight of imagination is needed to see that not enough collateral would be available should calls for additional collateral occur on a wider scale across the market, which is exactly the mechanism that caused the AIG insolvency during the financial crisis. Any defaults on calls for additional collateral would trigger liquidation under the relevant master agreements. Thus, insufficient initial margin, to the extent made possible by the insolvency safe harbours, would therefore appear to be a significant crisis accelerator. ${ }^{47}$

In conclusion, the above example illustrates how the safe harbour rules contained in the FCD and USC Title 11 can limit and spread contagion at the same time - 'which effect is more important is conceptually indeterminate'. 48

\section{BANK RESOLUTION}

After the financial crisis, a new way of dealing with the failure of large financial institutions has been conceived and implemented in the EU and the US. ${ }^{49}$ Big,

45 Roe, 'Derivatives Market Payment Priorities' (n 22) 563.

46 Roe, ibid, 573; Mooney, 'The Bankruptcy Code’s Safe Harbors' (n 19) 257; Skeel and Jackson, 'Transaction Consistency' (n 39) 190-191.

${ }^{47}$ See FSB, 'Implementing OTC Derivatives Market Reform' (2010) para 3.6.2

<http://www.financialstabilityboard.org/wp-content/uploads/r_101025.pdf > accessed 22 March 2015.

48 Roe, 'Derivatives Market Payment Priorities' (n 22) 566-567. See Edwards and Morrison, 'Derivatives and the Bankruptcy Code' (n 20) 2.

49 The US introduced this mechanism in the Federal Deposit Insurance Act in 1991 to address negative externalities potentially caused by the exercise of termination rights. The FDIA was originally applicable to institutions with a banking licence. After the Financial Crisis, the US modelled a broader rule on the FDIA that was included in the Dodd-Frank Act, sections 201(a)(11), 203, now also covering bank holding companies and, under certain conditions, non-banks. England and Germany adopted similar rules in 2009 and 2010. Also in 2010, the mechanism was elevated to global best practice by the FSB and several jurisdictions have since followed suit. In 2011, the FSB published twelve main features of effective resolution regimes which were updated in October 2014; see Financial Stability Board, Key Attributes of Effective Resolution Regimes for Financial Institutions (2014) < http:/ /www.financialstabilityboard.org/wpcontent/uploads/r_141015.pdf $>$ accessed 10 March 2015. The EU introduced a common rule in 2014 which is to be implemented in all Member States by 2015; see Directive 2014/59/EU of the European Parliament and of the Council of 15 May 2014 establishing a framework for the recovery and resolution of credit institutions and investment firms and amending Council Directive 82/891/EEC, and Directives 2001/24/EC, 2002/47/EC, 2004/25/EC, 2005/56/EC, 2007/36/EC, 2011/35/EU, 2012/30/EU and 2013/36/EU, and Regulations (EU) No 1093/2010 and (EU) No 648/2012, of the European Parliament and of the Council [2014] OJ L173/190. 
irreplaceable or highly interconnected ${ }^{50}$ banks and investment firms ${ }^{51}$ and, increasingly, financial market infrastructures, ${ }^{52}$ will no longer enter into insolvency proceedings but instead will be 'resolved'. Authorities will now in practice use this new, special administrative procedure to stave off consequences of the kind experienced in the wake of the Lehman failure, deploying various tools such as transferring viable business to a state-owned bridge bank or a healthy other bank, or converting debt owed by the failing institution into shares of it ('bail-in').

Despite supervisors and legislators insisting that insolvency is still the default option, in reality insolvency of systemically important financial institutions is becoming a well-nigh redundant concept. Insolvency laws are not even triggered as resolution is ordered by the relevant authority before insolvency proceedings have been commenced. Hence, there will be no insolvency official or court involved and the usual 'threats' to derivatives and repo portfolios, such as avoidance for preference will not be available. The rules of the FCD and Title 11 USC do not apply in these cases. Their safe harbour provisions will therefore remain relevant only to the counterparties of failing financial institutions that are not resolved but enter insolvency proceedings.

Regularly, master agreements allow for termination and close-out of repo and derivatives portfolios upon reorganisation or restructuring of the ailing party, ${ }^{53}$ ie before insolvency. However, these clauses will generally be ineffective as resolution eschews the route of privileged treatment through a safe harbour-like mechanism. Instead, resolution espouses the idea of an administrative stay or moratorium in respect of derivative and repo portfolios. The stay/moratorium operates either automatically, or may, and probably as a rule will, be imposed on the counterparties of the institution under resolution by the resolution authority. ${ }^{54}$ In that, resolution procedures embrace an approach which is well-known from general insolvency law that applies to non-privileged parties.

\footnotetext{
${ }^{50}$ International Monetary Fund/Bank for International Settlements/Financial Stability Board, Guidance to Assess the Systemic Importance of Financial Institutions, Markets and Instruments: Initial Considerations (2009) paras 12-15 < http://www.bis.org/publ/othp07.pdf> accessed 10 March 2015.

${ }^{51}$ See article 1(1)(a) BRRD; sections 201(a)(7), (8), (11), 203(b) Dodd-Frank Act.

${ }^{52}$ Committee on Payments and Market Infrastructures/International Organization of Securities Commissions, Recovery of Financial Market Infrastructures (2014) para 2.2.3

<http://www.iosco.org/library/pubdocs/pdf/IOSCOPD455.pdf> accessed 10 March 2015; Financial Stability Board (n 94) para 1.2. In the EU, the Consultation on a framework for the recovery and resolution of financial institutions other than banks was closed on 28 December 2012. No further steps have been taken so far. Under US law, large parts of the financial market infrastructure are already covered; see sections 201(a)(8), (11), (14), 102(a)(4)(C) DoddFrank Act.

${ }^{53}$ See, for example, sections 10(a)(vi), (b)-(g), 2(a)(v) of the 2011 Global Master Repurchase Agreement; section 5(a)(vii) ISDA 2002 Master Agreement: 'a general assignment, arrangement or composition with or for the benefit of its creditors' is assigned to be an Event of Default and Termination Event.

54 Articles 69-71 BRRD; section 210(c)(10)(B) Dodd-Frank Act.
} 
The administrative stay on termination, set-off and enforcement of collateral was introduced to allow the competent authority to evaluate the financial contracts of an ailing institution and to decide which could be transferred to a healthy acquirer and which should remain in the ailing estate and be wound up. The idea is also to avoid important changes on the balance sheet caused by extensive exercise of termination rights. ${ }^{55}$ Resolution regimes are more clear-cut in this regard than insolvency laws. There are no exceptions from the administrative stay comparable to safe harbour rules in insolvency law. ${ }^{56}$ Indeed, the stay typically ends after two days and termination rights do not re-emerge in relation to those parts of the business saved by the regulator, in particular by transferring them to a financially healthy institution such as another bank. Termination rights are only revived in respect of those contracts which remain in the now isolated 'toxic' part of the estate which is destined to be liquidated by recourse to ordinary liquidation proceedings. ${ }^{57}$ But this rump estate would typically not be of systemic importance.

Comparable to insolvency proceedings, bank resolution allocates losses and risks amongst creditors in the wider sense, including contractual counterparties (which in turn include general creditors, bondholders, depositors), shareholders and, society. It notably tries to tamper any systemic implications of the failure of a bank, avoiding that society actually becomes the main loss-bearing creditor, as is the case in the scenario of state bail out. However, if systemic risk is increasingly brought under control by bank resolution, 'what then remains of the original rationale for the safe harbours? 58

In fact, the scope of application of insolvency to failing banks has shrunk considerably since the introduction of bank resolution procedures. As a consequence, when examining the different scenarios, it becomes clear that insolvency proceedings with the aim of liquidating the relevant entity are nowadays well-nigh irrelevant in practical terms (despite their continued conceptual relevance for risk allocation). Counterparties of an ailing financial institution will now be able to trigger close-out and enforcement of collateral only under certain circumstances, depending on the concrete scenario.

Firstly, there are counterparties that are not covered by safe harbour rules as a function of their own nature. This group comprises real economy actors but also certain types of financial institutions: while banks and investment firms are generally within the scope, for example, insurance companies are covered in

\footnotetext{
${ }^{55}$ Recital (94) BRRD.

${ }^{56}$ However, title transfer financial collateral arrangements and set-off and netting arrangements shall be protected against split-up in the event of a transfer; see article 77 BRRD.

${ }^{57}$ Articles 71(1)-(5), 118 BRRD. The suspension does not, however, apply where the counterparty is a central bank, a central counterparty or a settlement system, ibid (3); section 210(c)(8)(A) and (10)(B) Dodd-Frank Act.

${ }^{58}$ Morrison, Roe and Sontchi, 'Rolling Back the Repo Safe Harbors' (n 39) 3.
} 
certain jurisdictions, but not in others. ${ }^{59}$ They are probably not systemically important to the financial sector.

Secondly, insolvency safe harbours will still in principle apply to those financial market actors which fall within their scope of application, notably banks and investment firms. However, to the extent that such an entity contracts with a systemically important one the safe harbour will in practice have no effect as the systemically important counterparty will enter resolution under the BRRD or the Dodd-Frank Act, respectively. Hence, safe harbour rules only take effect in practice for banks and investment firms to the extent they are contracting with systemically irrelevant counterparties.

As a result, the safe harbour rules will remain without effect in the most systemically relevant failures, notably those of systemically relevant banks, investment firms and infrastructures. Instead, regulators will use a completely different set of legal mechanisms to avoid contagion, including a stay on termination of contracts. Where insolvency proceedings may still occur, notably upon failure of a systemically irrelevant financial institution, the systemic risk rationale of safe harbours does not bite: the failure of such an institution is unlikely to contribute significantly to systemic risk, either through knock-on effects on counterparties or by leading to a liquidity crunch. ${ }^{60}$

Thus, it is probably fair to state that the introduction of bank resolution regimes has considerably reduced the scope of application of safe harbours mainly to systemically irrelevant scenarios.

\section{CAPITAL REQUIREMENTS AND OTHER RESILIENCE- FOCUSSED REGULATION}

Safe harbours, in practice, have lost most of their relevance in terms of reducing risk in the event of an actual failure of financial institutions. However, safe harbours are more than a building block of risk management inside financial institutions, where the amounts at risk in the counterparty's insolvency are the indicator for the credit risk a financial institution is running. They also conceptually intertwined with resilience-focussed financial regulation. In particular, bank capital requirements refer to safe harbour rules, recognising their risk reducing effect. At the same time, new regulatory approaches more specifically address the vulnerability to adverse market developments of collateral arrangements, thus aiming at mitigating any negative impact the safe-harbourinduced high levels of liquidity may have on financial stability.

\footnotetext{
${ }^{59}$ See P Paech, The need for an international instrument on the enforceability of close-out netting in general and in the context of bank resolution, Unidroit, March 2011, S78c Doc.2, 30. ${ }^{60}$ Bliss and Kaufman, Derivatives and Systemic Risk (n 9) 17.
} 


\subsection{CAPITAL REQUIREMENTS AND SAFE HARBOURS}

Banking regulation sanctions the risk reducing effect of safe-harbour-protected master agreements which govern banks repo and derivatives portfolios. Notably, the Basel Accord recognizes the net exposures used by financial institutions for risk management purposes also with a view to calculating capital requirements. The relevant regulatory rules require absolute certainty that close-out netting and collateral will be enforceable in the event of insolvency, ie it requires safe harbour rules to work smoothly and reliably. ${ }^{61}$ If that is so, banks are allowed to calculate their regulatory capital on the basis of net risk. Otherwise, repo and derivatives portfolios need to be accounted for with their gross risk. The average risk reduction through close-out netting alone is roughly $80 \%$. In order to grasp the effect of this significant reduction, it may be helpful to recall that regulatory capital is not, as is often assumed, a requirement to hold certain cash reserves available. Rather, regulatory capital describes the ratio between risk exposure and the capital raised by issuing own shares. As a consequence of the recognition of net risk of repo and derivatives portfolios, a bank is able to enter six times the gross risk in its balance sheet than it would otherwise be allowed to accept. ${ }^{62}$

The effect is two-fold. ${ }^{63}$ First, availability and liquidity of repo transactions are improved because absolute regulatory limits accommodate a higher volume where calculation on a net basis is allowed. This effect is not necessarily confined to derivatives and repo transactions but extends across the balance sheet to any other risk-taking activity such as ordinary lending. If as a consequence of the special protection less capital is needed to match derivatives and repo transactions, ordinary lending activity may likewise be increased. The second effect is a costsaving element for banks, since share capital is a relatively expensive means of financing. If contracts of a higher aggregate volume can be entered on the basis of the relevant available share capital base, their relative cost decreases.

\footnotetext{
${ }^{61}$ Bank for International Settlements/Basel Committee on Banking Supervision, 'International Convergence of Capital Measurement and Capital Standards (Comprehensive version)' (June 2006 - 'Basel II Accord') paras 117, 118, 139, 188 <www.bis.org/publ/ bcbs128.htm> accessed on 15 March 2015; 'Strengthening the resilience of the banking sector' (December 2009) 43 <www.bis.org/publ/bcbs164.pdf?noframes=1> accessed 15 March 2015.

${ }^{62}$ By way of a simplified example: a bank's derivative and repo portfolio is taken into account at a gross risk of 1000 GBP because there are no safe harbours. This risk needs to be matched, at the current minimum rate of $10.5 \%$ regulatory capital, by 105 GBP in own share capital. In other words, the amount of issued share capital limits the possibility to take on more risk. However, if netting is allowed the bank can, on the basis of the same 105 GBP in share capital, enter into contracts exposing it to a gross risk of 5000 GBP if we assume that close-out netting reduces the gross risk by $80 \%$.

${ }^{63}$ See Paech, 'The Need for an International Instrument on close-out netting' (n 59) 16-19.
} 


\subsection{Regulation Aiming AT EFFECTIVE COLLATERALISATION ${ }^{64}$}

During the financial crisis entire market segments froze despite the fact that the relevant market participants had concluded master agreements, were collateralised and, hence, should have been theoretically safe from counterparty credit risk. As master agreements regularly include margining provisions, they were also, in principle, protected against any depreciation in value of their collateral assets. However, while there was no doubt regarding the enforceability of collateral arrangements, the devaluation of the relevant assets and the availability of sufficient collateral turned out to be highly problematic, spurring a feedback loop involving repeated margin calls and further asset value depreciation that ultimately lead to a collateral crunch - which was one of the core triggers in the initial phase of the crisis, originally induced by doubts regarding the value of repackaged mortgage-backed securities. In other terms, the concept of collateral did not meet the expectations in terms of providing a sufficient level of resilience against adverse market events, neither at the individual level nor, and this is the core issue, at the level of the market as a whole. In short, if pre-crisis collateral had actually been as rock-solid as it was supposed to be, the financial crisis would not have happened.

The starting point of my argument is the general vulnerability to asset value depreciation, which is intrinsic in both the concepts of collateral and traditional security. The phenomenon itself cannot be avoided. Instead, the financial system must rely on mechanisms that identify and mitigate potential systemic effects of asset value depreciation. As a consequence of the crisis, a number of measures have been discussed, many of them in the context of 'shadow banking'.

The initial environment in which the financial crisis unfolded was characterised, amongst other things, by credit ratings of asset-backed securities that were systematically too positive. This defect coupled with the phenomenon that market players tend to react in similar ways to changing market conditions (on rational or even irrational grounds). This herding effect can easily turn value adjustments and corresponding margin calls into a systemic issue. Therefore, avoiding systematic overvaluation of assets is the first step to ensure that the concept of collateral is able to provide the protection it expected to provide. Thus, the first, urgent, adjustment to make was to ensure more accurate valuation of assets that are taken as collateral. This is where recent regulation of rating agencies

\footnotetext{
${ }^{64}$ See, in particular, European Commission, Proposal for a Regulation of the European Parliament and of the Council on reporting and transparency of securities financing transactions (29.01.2014) COM(2014) 40 final < http://ec.europa.eu/transparency/regdoc /rep/1/2014/EN/1-2014-40-EN-F1-1.Pdf> accessed 9 April 2015; FSB, Strengthening Oversight and Regulation of Shadow Banking, (29.8.2013)

<http://www.financialstabilityboard.org/wp-content/uploads/r_130829a.pdf>; Regulatory Framework for Haircuts on non-centrally cleared securities Financing Transactions

(14.10.2014) http://www.financialstabilityboard.org/wp-content/uploads/r_141013a.pdf.
} 
comes into play, aiming at the improvement of the processes that lead to a rating ${ }^{65}$ and at the removal of systematic overreliance on them. ${ }^{66}$

The pre-crisis capital requirements regime was furthermore responsible for a closely connected problem. As a consequence of the cyclical nature of asset prices, banks may be well capitalised during phases of economic upturn but need to divest in times of economic contraction to avoid undercapitalisation. The value of collateral assets is immediately linked to this phenomenon: selling off assets causes further asset value depreciation, eventually resulting in an asset price downwards spiral. Hence, removing pro-cyclicality in capital requirements is a factor closely intertwined with the question of whether collateral can provide effective protection against counterparty and market risk or whether it unable to. ${ }^{67}$

Equally closely connected to the foregoing is a market practice that I briefly addressed earlier in this paper, ie that of posting initial collateral that does not cover the entire net risk of a derivatives or repo portfolio. Often, no collateral at all was effectively posted between big market players. Margin calls occur only as soon as the financial situation of one of the parties deteriorates. ${ }^{68}$ This kind of market behaviour has the potential to significantly exacerbate financial instability. There are good reasons for safe harbour regimes allowing for margining during the lifetime of the contract. The rational for allowing margining is to prevent unenforceability of collateral provided prior to insolvency, including collateral provided during a so-called suspect period. From the insolvency law perspective, this seems acceptable because there is no need for avoidance. ${ }^{69}$ If applied consistently, margining does not actually constitute preferential treatment. Other creditors are not disadvantaged because there is no net outflow of assets from the pool. However, safe harbour rules in many jurisdictions, including those of the FCD and USC Title 11, do not distinguish on the basis of the criterion of net outflow but restrict avoidance more generally. ${ }^{70}$ As a consequence, later delivery of collateral is not voidable even in cases in which there is a net outflow of value

\footnotetext{
65 This includes various measures aimed at the removal of conflicts of interests within CRAs and at the improvement of their methodology, see Regulation (EC) No 1060/2009 of the European Parliament and of the Council of 16 September 2009 on credit rating agencies (as last amended by Directive 2014/51/EU), Articles 6-10.

${ }^{66} \mathrm{Ibid}$, Articles 5a, 5b and 5c.

${ }^{67}$ See in particular the 'countercyclical buffer', Directive 2013/63/EU of the European Parliament and of the Council of 26 June 2013 on access to the activity of credit institutions and the prudential supervision of credit institutions, as amended, ['Capital Requirements Directive'] Article 130.

${ }^{68}$ See FSB, 'Implementing OTC Derivatives Market Reform' (2010) para 3.6.2

$<$ http://www.financialstabilityboard.org/wp-content/uploads/r_101025.pdf > accessed 22 March 2015.

${ }^{69}$ See Recital 16 Financial Collateral Directive.

${ }^{70}$ See, in particular, Recital 16 Financial Collateral Directive: 'The intention [of restricting avoidance] is merely that the provision of top-up or substitution financial collateral cannot be questioned on the sole basis that the relevant financial obligations existed before that financial collateral was provided, or that the financial collateral was provided during a prescribed period. ...' (emphasis added).
} 
from the estate. In practice, parties use this freedom in 'good times' to suspend the provision of initial margin for an indeterminate period, notably as long as the obligor is financially healthy. ${ }^{71}$ Yet this practice not only offends against the rationale for safe harbours, in that it does not merely reflects an increased obligation. ${ }^{72}$ It is particularly problematic in terms of systemic risk, as there is a significant danger that not enough collateral would be available should calls for additional collateral occur on a wider scale across the market. Any defaults on calls for additional collateral would trigger liquidation under the relevant master agreements. Thus, insufficient initial margin, to the extent made possible by the insolvency safe harbours, would appear to be a significant crisis accelerator. After the crisis, the international community set standards on initial margin. ${ }^{73}$ These standards pay particular attention to the equilibrium of systemic risk on the one hand and liquidity on the other hand, notably by imposing gradual requirements that are also phased in over a longer period.

These measures are complemented by regulation requiring 'mandatory haircuts'; these are risk management measures whereby the value of collateral assets is calculated as their market value reduced by a certain percentage (the 'haircut'). A collateral taker applies haircuts in order to protect itself from losses resulting from declines in the market value of the collateral asset in the event that it needs to liquidate that collateral. 'Mandatory' haircut refers to a legal requirement to apply such abatement for risk management purposes. ${ }^{74}$

These regulatory rules are conceived directly to address the systemic risk flowing from the use of repos and derivative transactions. It would not be possible to achieve similarly well-calibrated solutions to that problem by abolishing or restricting safe harbour regimes — such an approach would be too bold and the resulting legal uncertainty would paralyse the market, as nobody would be able to rely on the enforceability of contractual risk mitigation.

${ }^{71}$ Roe, 'Derivatives Market Payment Priorities' (n 22) 563.

72 Roe, ibid., 573; Mooney, 'The Bankruptcy Code's Safe Harbors' (n 19) 257; Skeel and Jackson, 'Transaction Consistency' (n 46) 190-191.

${ }_{73}$ Basel Committee on Banking Supervision and Board of the International Organisation of Securities Commissions, 'Margin requirements for non-centrally cleared derivatives' (March 2015) < http://www.bis.org/bcbs/publ/d317.htm> accessed 17 March 2015; IOSCO Committee on Payment and Settlement Systems, 'Principles for Financial Market Infrastructures' (April 2012) Principle 6 <http://www.bis.org/cpmi/publ/d101a.pdf>; Regulation (EU) No 648/2012 of the European Parliament and of the Council of 4 July 2012 on OTC derivatives, central counterparties and trade repositories (commonly called 'EMIR') Article 46(1).

74 See European Central Bank online glossary, <https://www.ecb.europa.eu/home /glossary/html/glossh.en.html> accessed 10 March 2015; Basel Committee on Banking Supervision and Board of the International Organisation of Securities Commissions, 'Margin requirements for non-centrally cleared derivatives' (March 2015) < http://www.bis.org /bcbs/publ/d317.htm> accessed 17 March 2015. 


\section{CONCLUSION}

The current approach as to how repo and derivatives portfolios are treated in the event of crisis appears to be somewhat confusing. On the one hand, risk measurement and management still focuses on the hypothesis of insolvency, deducing main risk indicators from the level of counterparty credit risk. Counterparty credit risk, in turn, is critically determined by the rules of insolvency law, which include the so called safe harbours that preserve enforceability of termination, close-out netting and collateral arrangements. In practice, however, these insolvency laws have lost most of their relevance, as insolvency of financial institutions became a well-nigh redundant concept, applicable only to systemically irrelevant market participants.

Still, safe harbour rules need to be maintained, as there is no better alternative to the somehow privileged treatment of repo and derivatives portfolios. It is, in particular, difficult to imagine that safe harbours could be disapplied without basically wiping out the market for repo and derivatives transactions. At the same time, it is important to realise that there is no need to do so from the point of view systemic risk: insolvency safe harbours are overall neutral as regards the creation of systemic risk. While they may contribute to it in certain scenarios they may also reduce it in other situations. Further, without a functioning safe harbour framework risks inherent in repo and derivatives portfolios would become incalculable and hence unacceptable from a commercial and regulatory viewpoint. Lastly, the financial market including its framework for prudential regulation is based on an existing, highly liquid repo and derivatives environment. As safe harbours considerably contribute to these high liquidity levels, while at the same time being risk-neutral, they ought to be maintained.

However, it is true that systemic risk may arise from significant repo and derivatives positions. The last financial crisis has shown that they can be the source of considerable instability. Hence, this risk needs to be addressed. After the financial crisis, new, regulation-based approaches were conceived with a view to target the various aspects that contribute to this risk. As systemic risk is typically multi-causal, its mitigation involves a combination of measures. In the present context, the first building block is the removal of moral hazard - an aim that is now pursued by the introduction of bank resolution regimes. In addition, more specific measures have been adopted with a view to decreasing systemic risk, notably by improving resilience of individual market participants and of the market as a whole. In relation to the dangers flowing from big repo and derivatives portfolios these new measures consist of the introduction of countercyclical buffers, various improvements regarding the quality of credit ratings, rules mandating a more consistent initial collateralisation and mandatory haircuts applied to collateral assets. These measures are a much more effective tool to keep systemic implications of repo and derivatives portfolios under control. 